\title{
De olho no futuro
}

\section{A look into the future}

\begin{abstract}
$A^{R}$ Revista Ciência \& Saúde ingressa no oitavo ano de existência com a publicação do seu décimo sétimo número. Na busca de um constante aperfeiçoamento dos seus processos e do seu produto final, iniciamos 2015 com uma reformulação e modernização do "layout" dos manuscritos. Essa nova "cara" reflete a característica de um periódico eletrônico preocupado em acompanhar a evolução dos dias atuais e suprir as expectativas de leitores cada vez mais exigentes, não só com o conteúdo, mas também com a forma.

Por outro lado, a partir de uma iniciativa institucional e visando a qualificação das publicações, passamos a contar com o Digital Object Identifier (DOI), da empresa CrossRef, para cada artigo publicado. A atribuição do DOI certamente aumentará a exposição dos manuscritos publicados, facilitando a sua busca e os mecanismos de indexação.

Dessa forma, agradeço, em nome de todo o Conselho Editorial da Revista, aos leitores, pesquisadores e apoiadores do periódico pela participação e confiança neste veículo. Esperamos estar atendendo às expectativas e desejamos um ano produtivo a todos.
\end{abstract}

Prof. Dr. Márcio Vinícius Fagundes Donadio Editor-Chefe 